\title{
Things That Should Not Be Said: Censorship and Self-Censorship in the Nepali Press Media, 2001-02
}

\author{
MICHAEL HUTT
}

\section{Introduction}

Scholars and researchers across a range of disciplines increasingly "read" South Asia only in English. After all, the subcontinent produces English-medium scholarship, journalism, and creative literature in copious measure, and the Indian novel in English occupies a dominant position on the world literature stage. That culture is rapidly globalizing is one of the truisms of our day. That the principal language of globalized culture is English is almost axiomatic throughout the Euro-American world and beyond, and the belief that mass media, the entertainment industry, and the Internet will entrench its position even further is rarely challenged.

These assumptions about globalization, however, ignore the explosion of locallanguage media that has taken place all across South Asia over the past three decades. In India, the number of daily newspapers grew from 875 in 1976 to 4,453 in 1995, with sales of Hindi dailies surpassing those of English for the first time in 1979. Similarly, in Nepal, where until 1990 only a few dozen newspapers were published on a regular basis, there are now said to be more than sixteen hundred newspapers, of which 230 are dailies. In India in 1976, 9.3 million newspapers were produced each day for a population of 617 million: fifteen dailies for every one thousand people. By 1996, this rate had nearly trebled, reaching forty-three dailies per one thousand people (all figures from Jeffrey 2000, 39, 48, 47; Press Council Nepal 2001). According to Robin Jeffrey:

Evidence from other times and places suggests that once this rate reaches about thirty newspapers for 1,000 people, very substantial proportions of populations are affected.

Michael Hutt (mh8@soas.ac.uk) is Professor of Nepali and Himalayan Studies, Department of the Languages and Cultures of South Asia at the School of Oriental and African Studies, London.

The field research for this article, conducted in Kathmandu in July 2002, was made possible by a research grant from the British Academy, to whom I am, as ever, most grateful. My thanks also to David Gellner, Pratyoush Onta, and Bhagirath Yogi for their helpful comments on an earlier draft.

The Journal of Asian Studies 65, no. 2 (May 2006):361-392.

(C) 2006 by the Association for Asian Studies, Inc. 
Styles of politics and reactions to events begin to change, and popular involvement in geographically far-flung "national" political questions becomes possible. (Jeffrey 2000, 47)

The growth of local-language print media can be explained partly in terms of the adoption by national governments of liberal market policies and the arrival of new technologies such as computer typesetting and the offset press, but it also demonstrates that rising levels of literacy have led to the emergence of a mass readership that reads South Asian languages, not English. This material, along with the broadcast media (principally radio for the vast majority), is the single greatest influence on South Asian public opinion. As the principal and busiest avenue of communication between the intelligentsia and the merely literate, it is of immense significance. And yet it remains little studied.

This article is an examination of one aspect of the bruising encounter that took place in Nepal in 2001 and 2002 between the newly acquired civil rights that buttressed the growing "popular involvement" referred to previously by Jeffrey and the old societal consensus, to which a powerful elite still clung. The argument implicit throughout this discussion is that although the broad outlines can be discerned and the distant sounds of this encounter heard in the English-medium discourse it has generated, it can only be fully comprehended through recourse to the languages and assumptions within which it is primarily embedded. The so-called bruising encounter referred to at the beginning of this paragraph has continued since the time of first writing, and with King Gyanendra's coup of February 1, 2005, it escalated into outright confrontation. The coup brought with it a new Emergency and a more stringent, more vigorously resisted form of press censorship. It is hoped that this discussion of the press in Nepal's recent past may enhance understandings of developments in its present and future.

The Constitution of the Kingdom of Nepal 1990 guaranteed rights of access to information, freedom of speech and opinion, and freedom of association. Further, the Printing Press and Publications Act 2048 (1991-92) guaranteed that the property of any registered press could not be confiscated by the government because of what it had printed, that no a priori censorship would be exercised over any printed matter except in conditions specified by law, and that the registration of a newspaper or magazine would not be canceled because of its content. During the period under consideration here, however, the exercise of these rights remained compromised by much older codes of deference and secrecy and by the insistence of the powerful that there were still certain "things that should not be said" (bhanna nabune kura) and certain questions that could not be asked.

Specifically, I chart and examine the workings of censorship and self-censorship in the Nepali press media coverage of two developments in the recent history of Nepal. These are (1) the massacre of King Birendra and his family at Narayanhiti Palace in Kathmandu on June 1, 2001, and (2) the declaration of a national emergency on November 26, 2001, and the subsequent military crackdown on Nepal's long-running Maoist insurgency. Most of my references are to the Nepali-language print media ${ }^{1}$ and particularly to those privately owned newspapers that aspire to the status of

${ }^{1}$ Nepal's English-language press is read only by a tiny urban elite plus expatriates, tourists, and Internet users. The English medium does have its own advantages when the state becomes censorious, as we shall see. 
national dailies and claim to be politically impartial. ${ }^{2}$ As well as providing some insights into some of the most important moments of recent Nepali history, my discussion is intended also to contribute to an understanding of the way in which the existence of bhanna nabune kura, and the self-censorship that is a consequence, reflected the rules of and constraints on Nepali public discourse that obtained during the period under consideration and will show how censorship was imposed, internalized, and eventually overcome by those whose voices it sought to muffle. I hope this will serve to demonstrate and underline the importance of attending everywhere to the crucial internal discourses that are conducted in non-global languages. ${ }^{3}$

\section{Nepal's Modern Political History: A Thumbnail Sketch}

The modern political history of Nepal begins with the so-called unification of the country during the late eighteenth century by a military force recruited from the hill communities of west-central Nepal by the Shah kings of Gorkha. Continued expansion led to conflict with the British and eventually to the establishment of agreed geopolitical boundaries in 1816. In the mid-nineteenth century, there began a 105-year period of autocratic rule by the Rana family. The Ranas established the Legal Code (Muluki Ain) that ranked the entire population in a caste hierarchy, and they intermarried with the Shahs to produce a landed aristocratic elite. This elite still possesses significant business interests and occupies most positions of senior command in the Royal Nepalese Army.

Nepal's first political parties (the Praja Parishad, the Nepali [National] Congress, and the Nepal Communist Party) were established during the 1930s and 1940s. The departure of the British from India strengthened the hand of anti-Rana forces (both liberal and monarchical), which brought about the end of the regime in an Indiansponsored political settlement in 1951. The new political dispensation led eventually to the election of a Nepali Congress government in 1959, but in December 1960 this was dismissed by King Mahendra, using emergency powers granted by the 1959 constitution, and many of its leaders were imprisoned or exiled. Mahendra claimed that the government was failing to maintain law and order and was endangering Nepal's national sovereignty. The partyless (nirdaliya) Panchayat system, established in 1962, was presented as a system of grassroots democracy that was better suited to Nepal's traditions and conditions than the imported Westminster parliamentary model. The new system became increasingly unrepresentative, exclusive, and corrupt, however, and was finally dismantled in the wake of the People's Movement (Jan Andolan) of 1990. The Jan Andolan reinstated multiparty (babudaliya) democracy, and an interim government tried to ensure that the new constitution, promulgated in November 1990, reduced the powers of the monarchy.

The Nepali Congress and the Communist Party of Nepal (United MarxistLeninist, UML) were the principal party political forces from 1990 until the disso-

${ }^{2}$ The editorial lines taken by the more recognizably partisan press, of which there is no dearth in Nepal, are more predictable and, therefore, rather less interesting for the present discussion than those taken by newspapers that wish to establish impartial credentials.

${ }^{3}$ This discussion should not be taken as an overall evaluation of the mainstream independent Nepali press, which has emerged in its current shape and form mainly since 1990. Nor should developments during the period under consideration be taken as examples of a more general trend: The speed and boldness with which a whole range of sensitive issues were tackled between October 2002 and February 2005, including the proposal that Nepal should be made a republican state, must give the lie to that supposition. 
lution of the House of Representatives (pratinidhi sabha) in May 2002. The Nepali Congress was in government, either solely or as a member of a coalition, for most of these years, whereas the UML served as the main party of opposition, with a brief spell as the sole party in office in 1994-95. The 1990s witnessed a growing public disenchantment with the new dispensation, of which the most extreme manifestation was the People's War (jan-yuddha), launched by the Communist Party of Nepal (Maoist) in February 1996. ${ }^{4}$ The rebels were quickly able to carve out base areas of exclusive Maoist control in the midwestern hills, opposed only by a demoralized police force. The massacre of King Birendra and his family on June 1, 2001, was apparently unconnected with the People's War, but it came at a time of increasing violence between the Maoist rebels and the state's security forces. After a three-month ceasefire during which negotiations took place, the Maoists resumed the armed struggle, and a state of national emergency was declared in late November 2001. The Royal Nepalese Army was deployed against the Maoists, now labeled terrorists, and nine months of civil war and military rule ensued, claiming the lives of some four thousand people. ${ }^{5}$ The majority of these died at the hands of the security forces and included Maoist cadres and paramilitaries, alleged Maoist supporters, and apolitical civilians. The fragility of the freedoms won by the Jan Andolan in 1990 became ever more apparent, and the number of "things that should not be said" increased.

Nepal's democracy was also swiftly dismantled. The House of Representatives was dissolved in May 2002. The terms of office of local government bodies expired in July 2002, and no new elections were held. In the semicoup of October 2002, the king dismissed the prime minister for his inability to conduct general elections and during the next twenty-eight months appointed three different governments. Meanwhile, most of the major parties took to the streets in protest at this regression. A second cease-fire was agreed in January 2003, and negotiations were resumed, but the ceasefire broke down once again in August 2003. Finally, on February 1, 2005, King Gyanendra took all executive power to himself; declared a national emergency; placed all Nepal's leading politicians under house arrest; shut down the country's phone system, Internet servers, and FM radio stations; diverted international flights; and imposed strong press censorship. He assumed the chairmanship of a handpicked tenmember Council of Ministers and announced that he would produce a plan for restoring basic freedoms within one hundred days but would exercise direct rule for three years. He then proceeded to establish a system of government that looked very like the Panchayat system of the early 1960s (Hutt, 2005). Just a few weeks before this article went to press, a second Jan Andolan in Nepal, based upon an agreement reached between the Maoists and seven political parties in November 2005, forced the king to reinstate the House of Representatives. Nepal has therefore entered a new phase of its political history.

\section{Newspapers in Nepal}

The history of newspaper publishing in Nepal is usually dated from 1901, when the Rana ruler Dev Shamsher established the government organ Gorkhapatra; this was

${ }^{4}$ The sociopolitical causes of this insurgency and the chronology of events since it began in 1996 have been extensively documented elsewhere (see Gellner 2003; Hutt 2004; Karki and Seddon 2003; Kumar 2000; Thapa 2002, 2003).

${ }^{5}$ This brought the total number of casualties since the beginning of the People's War to about eight thousand; by the end of January 2005, this total had risen to nearly eleven thousand. 
one among several acts of uncharacteristic liberalism that led to him being toppled from power after only three months in office. The Gorkhapatra survived him, however, and, until 1990, Nepal's most powerful news media (primarily, the Gorkhapatra daily, its English-language sister publication The Rising Nepal, Radio Nepal, and Nepal Television, established in 1986) remained state-owned. The two newspapers employed their own journalists and stringers but drew much of their news content from Nepal's only news agency, the Rastriya Samachar Samiti (rasas). Under the Panchayat regime (1962-90), the nonstate media amounted to little more than a handful of weekly papers, each owned by private individuals with known but undeclared links to one or other of the banned political parties.

One of the most striking features of urban Nepali life since 1990 has been a dramatic increase in not only the number but also the quality of newspapers and magazines. By 2001, according to Nepal's Press Council, 1,620 newspapers were being published on a regular basis in Nepal. ${ }^{6}$ Of these, the vast majority $(1,156)$ were weekly papers, whereas 230 were dailies. More than half of all newspapers (866) published in Nepal were published in the central Bagmati zone, and 735 of these (including 106 dailies) emanated from the capital, Kathmandu. A vast majority $(1,345)$ were published in Nepali, with 61 published in English and a further 130 appearing in Nepali and English (Press Council Nepal 2001, 46, 52, 62). A further sprinkling of newspapers was published in other Nepalese languages.

The most significant development in this media boom was the establishment in 1993 of the broadsheet dailies Kantipur (in Nepali) and The Kathmandu Post (in English), whose production quality and editorial standards were so self-evidently superior to those of the government-owned papers that they quickly became market leaders. Daily sales of Kantipur were estimated to be between seventy thousand and ninety thousand in mid-2002. ${ }^{7}$ Kantipur, a substantial broadsheet paper, is of much greater significance for Nepali public opinion than its English-language sister, which is read mainly by expatriates and tourists. The main challengers to this pair during 200102 were Nepal Samacharpatra (in Nepali), Himalaya Times (in Nepali), the Himalayan Times (in English), Spacetime Dainik (in Nepali), Spacetime Daily (in English, though this version was withdrawn in 2003), and the then newly established Rajdhani (in Nepali). The circulation of these Kathmandu papers has been estimated to range from seven thousand (presumably for the lowest-selling English version) to fifty thousand (Onta 2002, 254). Of course, circulation and sales figures are not a firm indication of the size of a readership. Jeffrey $(2000,47$, n. 79$)$ notes that Indian-language newspapers are "often held to have an average of at least five readers a copy."

The influence of the Nepali-language weekly newspapers, which are usually more cheaply produced and tabloid in format, declined somewhat as the marketplace filled with dailies. Filters on the news media operate just as fully in Nepal as they do elsewhere: The ownership of all media with any substantial outreach is limited by the large size of the investment that is required, and advertising is the primary income source (Herman and Chomsky 1994, 2, 4, 15).

The emergence of high-quality news magazines was another striking development of the 1990s. A circulation of around fifty thousand was estimated for the fortnightly Himal Khabarpatrika, whose publishers also produced the English weekly the Nepali

${ }^{6}$ Devraj Humagai $(2002,123-25)$ provides some information on the Press Council's survey methods. It seems likely that although the number of newspapers registered in Nepal is probably close to the number cited, rather fewer of them are actually published regularly.

${ }^{7}$ Yubaraj Ghimire, Personal communication with author, July 11, 2002. 
Times. Kantipur Publications' magazine Nepal was a close rival. A second tier of news magazines was typified by a magazine such as Mulyankan, a left-leaning fortnightly with a circulation of around thirty thousand.

James Curran writes that, according to the received account, the development of the British press passed through three phases. It began as an extension of the state, then became an extension of the party political system, and then (from the 1940s onward):

The press came to be managed by market-led pragmatists who sought to maximise sales rather than further a political viewpoint. This established allegedly the consumer as the ultimate controller of the press, and transformed newspapers into representatives of the public rather than of organized political interests. (Curran 1992, 91)

This process of development may be said to be mirrored in the history of the Nepali press but with the second phase beginning only late in the 1960s and the third after 1990. The period of multiparty democracy (1990-2002) saw the circulation of a mixture of party-aligned papers and papers driven primarily by the urge to secure a large market.

\section{The Royal Massacre and the Nepali Press}

On the evening of Friday, June 1, 2001 (19 Jeth, 2058), King Birendra and the whole of his immediate family were either killed or fatally injured by gunfire while they were attending their customary monthly gathering at the Narayanhiti Palace in Kathmandu. Birendra, Queen Aishwarya, their younger son, Nirajan, and their only daughter, Shruti, were pronounced dead at the Birendra Military Hospital shortly after the incident. Their elder son, Dipendra, was declared king as he lay in a coma and then pronounced dead on June 4. Five other relatives also died of gunshot wounds, including Dhirendra Shah, one of Birendra's two younger brothers. Over the following days, the news spread quickly that Dipendra had shot dead his parents, his two siblings, and five other relations, injured three others, and had then shot himself in the head. Gyanendra, Birendra's only surviving brother, became king on June 4.

Rumors spread rapidly in the immediate aftermath of the massacre. The situation was not helped by the fact that the palace retreated behind its traditional veil of secrecy or by the suggestion, made first by Gyanendra on June 3 and later by a palace secretary speaking to the international media, that the incident had been caused by the sudden (achanak) or "accidental" firing of an automatic weapons. ${ }^{8}$ Conspiracy theories multiplied, fueled by suspicions that Gyanendra, perceived as the chief beneficiary of the massacre, might have had some hand in planning it and by the widespread public unpopularity of his eldest son, Paras, who was implicated in some wellknown drunk-driving incidents, of which at least one had led to a fatality. Demonstrators came out on the streets of every major town to express their fury and disbelief, and six were killed by police deployed to quell the protests. For several days, the capital was placed under a curfew, and on June 4, the body of Dipendra was conveyed to the burning ghats at Pashupati Temple while its streets were all but

${ }^{8}$ The Nepali word translated as "accidentally" was achanak, which actually means "sudden," with no indication of whether the actions or events thus described are intentional or accidental. The international media, inevitably, picked up on "accidentally," and palace sources made no effort to correct the mistranslation. 
empty. Gyanendra's ascent to the throne took place on the same day under similar conditions, though on his way back to his palace, the new king had to witness a public demonstration in which people were shouting slogans against him. On June 4, Kantipur ran a front-page story with a photo, under the headline "Shokmagna janata ghatna sarvajanik garna mag gardai sarakma” (Grief-Stricken Public on Streets Demanding that Event Be Made Public):

On Sunday [June 3], youths chanted slogans on the street in front of the palace, demanding that [details of] the incident be made public. The demonstrations emerged in an unexpected and unprecedented manner in the capital and several other cities, and the demonstrators expressed the opinion that the incident had been a conspiracy. They also expressed their anger (akrosh) toward rajya sahayak Gyanendra ${ }^{9}$ and Prince Paras. (Parajuli 2002, 60) ${ }^{10}$

Immediately after he was crowned, Gyanendra announced that a high-level commission would carry out an investigation of the massacre. In the event, the commission consisted of only two people- the chief justice and the speaker of the Nepali parliament (a member of the ruling Nepali Congress Party) — after the leader of the opposition, Madhav Kumar Nepal, withdrew from it. It began its investigation on June 8 and completed it in six days. A 196-page report, consisting mainly of verbatim transcripts of interviews with eyewitnesses, was released within a week. ${ }^{11}$ The eyewitnesses all related how Dipendra had shot dead his parents and both of his siblings and had also shot eight other relatives, of whom only three survived. They also reported that he had consumed a quantity of whisky, cannabis, and another unknown narcotic that evening. One eyewitness (Paras Shah) claimed that Dipendra had for some time been at loggerheads with his family (and with his mother in particular) over his wish to marry Devyani Rana, the daughter of a leading Nepali politician and businessman. ${ }^{12}$ The report contained a number of contradictions, however, and left many questions unanswered. For instance, how could an individual who was deeply intoxicated gun down twelve individuals on a highly selective basis, killing all but three? Why was it that every member of Birendra's bloodline had been killed, whereas Gyanendra's son and daughter escaped unharmed? Why would Dipendra, who was right-handed, shoot himself in the left side of his head? How could the Nepali public believe that Dipendra, a generally popular royal who had been seen acting completely normally in public at a Sports Council function that very day, was capable of such crimes? Many Nepalis (probably a majority of the population) remained unconvinced. Even those who accepted the version of events recorded in the official report argued that more details should be made public:

Distasteful events related to Kathmandu royalty have historically been swept under the feudal carpet, with society having to move along with a less-than-complete version of events. This cannot be so in the present age, nor is it in the interest of the country, but that is indeed what is happening. (Dixit 2002b, 70)

${ }^{9}$ Gyanendra was proclaimed rajya sabayak, literally "kingdom assistant" but widely translated as "regent," after Dipendra, who remained in a coma, was proclaimed king.

${ }^{10}$ All translations from the original Nepali are my own.

${ }^{11}$ Narayanhiti parva: vistrit prativedan (The Narayanhiti Incident: Full Report). n.p., n.d. Available from 246224 Bagbazaar, Kathmandu.

${ }^{12}$ Pashupati Shamsher J. B. Rana was at the time the chairman of the Rashtriya Prajatantra, or National Democratic Party, which was generally seen as the most conservative and propalace of Nepal's parliamentary parties. 
Radio Nepal and Nepal Television effectively closed down for some fourteen hours after the massacre. The TV station simply broadcast solemn music over a still photograph of Pashupati Temple. As the independent-left writer Khagendra Sangraula recalls:

I went and sat in front of a television that belonged to a nurse who lived in the next room. There is a democratic government in this country. It is very eager to chant the mantra of the citizen's right to information and transparency. Therefore, many eyes were turned toward Nepal Television, and we sat holding our breath. As soon as the television began, there began the wailing of Hay Ram, Sita Ram. But Hay Ram for whom, Sita Ram for whom? The brainless (vivek gum bhaeko) television told us nothing at all. (Sangraula 2001a).

Only two of Nepal's national dailies carried a report of the massacre the next morning. The fact that all other papers remained silent on the matter was not because they had not received any information. Rather, according to the media analyst Rama Parajuli:

This was due to the complexity of the subject, which meant that the dangers [involved in reporting it] had not been evaluated. If a prime minister had been murdered . . . no newspaper would have neglected to report on it, but because the incident involved the king and the royal family, the newspapers preferred to remain silent. The major newspapers were taken to be the one major genre (vidha) that had become the strongest and healthiest in the open atmosphere provided by the democracy established by the Jan Andolan of 1990, but this event demonstrated that they had not yet become fearless and strong. (Parajuli 2002, 53)

Another writer on the subject goes farther, stating:

A journalist is taught to be curious about everything. But there was no evidence of any such curiosity in the daily papers' conveying of the news of the palace massacre. The dailies were misled (bahakie). If we use the saying "News is what people try to conceal, the things that people try to reveal are advertisements" as a basis, then our daily papers printed only advertisements at the time of the Narayanhiti Palace massacre and afterward. They did not try to seek out news, nor did they dare to print it. (Adhikari 2002, 75)

Kantipur and its English-language sister publication the Kathmandu Post each published a four-page special issue on the evening of June 2. These gave an account of what was then known of events in the palace, announced that Crown Prince Dipendra had been declared king, and urged the public to remain calm. The other national dailies waited until the next day to begin their coverage, and each adopted a similar version of the story. Each newspaper also cited a disagreement over Dipendra's choice of marriage partner as the main reason for his murderous rampage.

Although Nepal's government-owned media maintained their silence and the private media agonized over how to cover the news, the foreign and Internet media began to run the story within about four hours of the event:

Then we went across the seven seas. Under the partyless regime of yesterday, which tried to prolong its life by suppressing truthful information, we used to do this. Now, in this multiparty time. . . we were forced to do the same again. News of the massacre had already spread everywhere overseas. (Sangraula 2001a)

Although the foreign media unanimously identified Dipendra's unfulfilled wish to marry Devyani Rana as the main causal factor, this did not become part of the 
domestic coverage until June 3. After the official report had been published, all the national dailies reproduced verbatim the transcript it contained of a telephone conversation with Devyani Rana. Parajuli $(2002,54)$ complains that none of these reports produced any evidence to support the assertion that the marriage issue lay behind the killings, nor did any of them query how it was that an individual under the influence of drink and drugs could carry out such a massacre. On June 14 (Jeth 32), Kapil Kaphle published an article in the Nepal Samacharpatra entitled "Devyani rahasyako poko bokera timi kata bhagyau?" (Devyani, Where Have You Run to with Your Bundle of Secrets?), pleading with Devyani to return to Nepal and reveal all (Parajuli 2002, 58).

The press in a democratic society has been variously described as "a public watchdog," "a partner in the process of government," and "a representative of the public" (Curran 1992, 90-91). To what extent should national newspapers set out to create and influence public opinion, and to what extent should they act as a mouthpiece for it? There is, undoubtedly, a tension between these two roles, and this is heightened at a time when the establishment is trying to convince a skeptical public that what it is telling them is the truth. On the publication of the official report, all of Nepal's national dailies made the fact that the report had confirmed Dipendra as the killer their banner news headline but also reported the mixed response the report was getting from political parties and the public. In fact, the official explanation for the royal massacre created a schism in public opinion. Although it appears that the mass of the population remained unconvinced by it, certain influential members of the Kathmandu elite grew increasingly impatient with those who continued to cast doubt upon it. There was no evidence to support any other explanation, they argued, and the various conspiracy theories that were circulating were not only wrong, they were downright dangerous in the political context of the time. As John Stuart Mill wrote:

In the present age-which has been described as "destitute of faith, but terrified of scepticism"-in which people feel sure, not so much that their opinions are true, as that they should not know what to do without them-the claims of an opinion to be protected from public attack are rested not so much on its truth, as on its importance to society. (On Liberty, 1869)

Citing Bhupi Sherchan's famous poem "Yo Hallai-Hallako Desh Ho" (This Is a Country of Hearsay and Rumor), Kanak Mani Dixit, editor of Himal South Asia, criticized the palace for failing to release information quickly, or at all, but then sought to exonerate it: "With the tragic procession of dying kings and other royals throughout the weekend, there was no one to instruct palace underlings-miserly with information at the best of times-to open up." Dixit then poured great scorn on the Kathmandu intelligentsia:

\footnotetext{
Vacant minds easily ingest rumour, and this is the case of the Kathmandu intelligentsia, whose members have so little self-respect that they are willing to impute their own worst motives to others. Their tendency is always to be certain of a conspiracy when a simpler explanation may suffice. To stick to a straightforward explanation would require too much rationality. (Dixit 2001)
}

This elicited a strong response from Pratyoush Onta, who wrote:

Citizens of Nepal have the right to information regarding all aspects of what happened in the Narayanhity Palace on 1 June. Article Sixteen of our Constitution gives every Nepali citizen the right to demand and receive information about all subjects 
of public importance. Had the information bureaucracy of the Palace or the government been better managed, this right of the Nepali people would have been honoured through an initial announcement early in the morning on 2 June stating the known facts of the case. ... In the absence of such an announcement from relevant official quarters, Nepali people resorted to means that were accessible to them to exercise their right to information. Phone calls to sources in the know or just one's relatives, consumption of international electronic media (TV, radio and the internet), face-toface discussions to exchange information and similar activities must be seen in this light. When these activities too could not satiate demands for information, people came on the streets asking for more. Instead of calling these people $u$ danda [rebellious] and arajak [anarchic] (as the government did) or rumour-spreaders (as some respectable media commentators have done), we should interpret their actions as sovereign agents seeking means to exercise their right to information. That both the Palace and the state did not have institutional capacity to respond to their demands can hardly be construed as the fault of the people who came on the streets. And those who quote the last seven lines of Bhupi Sherchan's immortal poem on ours being a country of rumours on their way to a patronizing analysis of so-called rumour-spreaders, might want to reread its first 48 lines to think about how the best of our poets characterized the process that gives rise to hallas [rumors]. (Onta 2001)

The state moved to stem the flood of conspiracy theories on several occasions. Five booksellers were arrested in Kathmandu on June 22, 2001, apparently for selling books that set out alternative explanations for the royal massacre (Yogi 2002, 55). Later in the year, on October 21, a well-known street poet, Bhim Prasad Dulal, was also arrested and detained by the police for singing a song about the royal massacre in public. Those, like Dixit, who were angered by what they saw as irresponsible rumormongering recognized that the Maoist insurgency could draw only strength from a widespread public reading of this cataclysmic event as a political conspiracy. The Maoists were quick to realize this, too, and a piece entitled "Naya kotparva lai manyata dinu hundaina" (We Should Not Recognize the New Kot Massacre) appeared in Kantipur on June 6, 2001, under the byline of the leading Maoist ideologue, Baburam Bhattarai. Referring to the Kot massacre of 1846, in which Jang Bahadur Kunwar engineered the deaths of most of his political rivals, thus inaugurating the Ranas' century of autocratic rule, Bhattarai alleged that the massacre was the result of a conspiracy involving the Indian Research and Analysis Wing and unnamed imperialist forces. The purpose of the massacre, he said, was to replace a patriotic king (Birendra) with one who would do India's bidding (the parallel example given was that of Bhutan's Jigme Singye Wangchuck). Baburam Bhattarai praised the role played by certain members of the Shah dynasty in the preservation of Nepal's sovereignty and independence and claimed that the Maoists and the late king had been thinking along similar lines on many questions of national importance. His essay ended with an implicit call to the army to mutiny against the "puppet of expansionism born inside the palace" and to side instead with the "patriotic sons of Mother Nepal who have been born in huts" (Bhattarai 2001)

The paper's editor and the managing director and director of Kantipur Publications were arrested the very day Baburam Bhattarai's article appeared in their newspaper and charged with treason under the Offences against the State (Crime and Punishment) Act 1989, which carried a prison term of up to three years and a fine of Rs 3,000. They were released on June 15, and by the end of September the courts had upheld the government's decision to drop all charges (Yogi 2002, 53-54).

Subsequent issues of the national dailies contained a great deal of discussion and argument over the rights and wrongs of publishing this article. One set of commen- 
tators argued that the paper did not have the right to publish an article that came to objectionable conclusions about the causes of the royal massacre. They believed that press freedom had to be limited to avoid inflaming the public at a time when the palace and Nepal's democratic institutions were battling an insurgency. A second opinion was that although press freedom was sacred, Kantipur had acted irresponsibly by publishing such a piece at such a time. The third opinion expressed was that because the constitution vested the sovereignty of Nepal in its people, this guaranteed them the freedom "to say the most absurd, outrageous, illogical, and stupid of things, irrespective of the timing" (Onta 2001).

There was little or no discussion of the actual content of the piece, however. ${ }^{13}$ One issue that was not debated at all was the allegation made in the article of an "undeclared working unity" (aghoshit karyagat ekta) between the king and the Maoists. The Congress Party had long alleged that the key to the Maoist problem lay in the palace, but this had not been taken very seriously: How could republicans make common cause with a king? However, Kantipur had already reported a meeting between the Maoist leadership and a member of the National Assembly with close links to the palace. Prashanta Aryal concludes:

It is clear that a link existed between the Maoists and the palace. The connection, and the nature of the connection, needs to be investigated. The Nepali press did not want to comment on or analyze this claimed link between the palace and the Maoists or investigate whether it was real. (Aryal 2002, 30)

The mainstream Nepali dailies never went so far as to explicitly challenge the verdict on Dipendra. ${ }^{14}$ They contrived to give voice to continued public doubt, however, by regularly printing interviews and stories that attested to his good character. For instance, Rajdhani of June 13 carried a story by two of his tutors, and there were numerous interviews with his fellow students. Implicitly, the official story was being challenged, but this was never stated openly (Parajuli 2002, 59). The independentleft writer Khagendra Sangraula took this challenge just about as far as it could go in an article entitled "Bhatij Dipendra! Malai maph gara" (Nephew Dipendra! Forgive Me!), published on July 7, 2001 (Sangraula 2001b). Sangraula wrote that although Dipendra might well have lived on Mars for all the contact he had had with him, he had observed him from afar and wondered what kind of king he might make. He saw a peaceable, civilized, cheerful man who wanted to lower the tall palace walls and come closer to the ordinary people. After he died, however, his character had been transformed into that of a person who was:

mentally ill, a harmer of others and himself, crazed with love, astonishingly cruel, and an unimaginably criminal demon. A father-killer, a mother-killer, a brother-and sister-killer, an aunt-and uncle-killer, a killer of everyone. When I heard that news, which I had never expected even in a dream, my brain was unable to believe it and became bewildered (sanna), and it asked my inner heart: Could that Dipendra and this Dipendra be the same man? Could the image of Dipendra after June 1 be the manifestation of a demon Dipendra that had been hiding inside the beautiful exterior of the previous Dipendra? Could such a terrific (vikaral) difference exist between a

${ }^{13}$ Baburam Bhattarai's essay vanished from the Kantipur Web site archive in mid-2003.

${ }^{14}$ The overtly left-wing press, of course, took a different view. It has become an article of faith for Nepalese Maoists that Gyanendra was responsible for the murder of his brother, and their public statements regularly describe him as "fratricidal" and "regicidal," though not a shred of evidence has been produced to support this (see Lecomte-Tilouine 2004). 
person's external performance (abbinay) and the inner essence of their character? Can a person change so dramatically from one day to the next? Is a person's nature and mentality a hidden secret that cannot be made sense of by any thread of experience or knowledge, that cannot be guessed at in advance? An endless succession of questions arose in my mind. Meanwhile, the wise men who could understand and discern the truth were trying to outdo one another, like mynah birds in a bamboo grove, as they called out over the national and international communications media, "Yes, this is the very truth, the first and last. The lone character who destroyed his lineage is Dipendra. Only Dipendra, solely Dipendra, none other than Dipendra."

Although he never knew Dipendra, Sangraula wrote, Dipendra now follows him wherever he goes, protesting his innocence, crying out that although he is being presented as the greatest murderer in history, he is actually the victim of the greatest injustice in human history. Sangraula mocks the detective story contained in the official version of events, which, he says, has become an unchallengeable truth:

Do not doubt it, do not question it, do not debate it. They have leveled the weapons of power at those who doubt, question, or debate. Therefore, all around [people] are frightened, silent, resigned (udas).

Many mouths are shut beneath the shadow of terror. Many pens have taken a vow of silence. So many of the English-knowing postmodern feudalists are spreading the message across the world in their joy at having won the bet: "See? In the end, what we said has been proved true! It was Dipendra, Dipendra and only Dipendra!"15

The mainstream Nepali dailies were unable to interrogate the official account of and explanation for the royal massacre, despite the fact that the huge majority of their readership was extremely distrustful of it. Rama Parajuli records that when the main findings of the official report on the royal massacre were presented at a press conference, the assembled journalists were not permitted to ask any questions. Whereas the news media in a democracy should strive to occupy the middle ground between the government and the public, conveying the government's views to the public and vice versa, the enormous sensitivity of this issue at a time of virtual civil war meant that the traffic of opinion and information was much heavier in one direction than it was in the other. Public dissent could only be reflected obliquely in the pages of the nonrevolutionary Nepali press; all across the board, the huge majority of journalists and editors arrived at an assessment of the situation that led them to exercise extraordinary restraint.

\section{The Maoists, the Emergency, and the Nepali Press}

\section{The Maoists and the Press}

The Maoist movement increased competition between papers for news coverage for which their editors knew the readership would pay. ${ }^{16}$ The national dailies, in

${ }^{15}$ This essay appears with other poems and essays on related themes in a collection entitled Itihasma kalo potieko anuhar (A Face Painted Black in History) (Sangraula 2001c).

${ }^{16}$ Sales of newspapers were also said to have soared ("Maobadi kriyakalapka karan patrapatrikaka bikrima tivrata" [Sharp Increase in Newspaper Sales because of Maoist Activities], Rajdhani, November 25, 2001). Robin Jeffrey $(2000,77)$ identifies war as an event that provides "the impetus to carry newspapers beyond the circles to which they were previously confined." 
particular, became increasingly important not just as sources of information but as molders of public opinion. There are suggestions that their coverage also had some impact on the conduct of the Maoist campaign. Rajendra Dahal, however, has strongly criticized the Nepali press for a lack of balance and coherence (sangati) in its perspective on the Maoist People's War (Dahal 2002, 15), and Onta has extended this criticism to the whole of the Nepali intellectual elite, accusing it of extreme duplicity in its dealings with the Maoists (Onta 2004). It is true that in the years leading up to the Emergency of 2001-02, much of the ostensibly mainstream Nepali private media leaned toward the Maoists to some extent. As the Maoists gained ground, the mainstream Nepali press indulged them increasingly, and journalists began to drop the rider so-called (kathit) from their references to the People's War and criticized the atrocities perpetrated by the security forces more readily than those committed by the Maoists. Reports from the Maoists' base areas in the midwestern hills, to which the Maoist leadership granted Kathmandu-based journalists controlled access from time to time, were frequently criticized for being too soft on the Maoists. Thus, on the eve of Maoist-government negotiations in autumn 2001, the Maoist leader Krishna Bahadur Mahara, perhaps mischievously, thanked Nepali journalists for helping to bring the Maoist movement thus far, calling them an utprerak shakti or "inspirational force" (Aryal 2002, 29; Luintel 2002, 45). Of course, this pro-Maoist basis was also explained partly by the fact that those who dared to challenge the Maoists in print often received unambiguous threats (Dahal 2002, 16).

The relationship between the Maoists and the Nepali press deteriorated steadily as the violence grew worse. In September 2001, three journalists and two humanrights workers were detained for three days by Maoists in Rolpa district and informed that, no matter what they wrote, they were still "reactionary journalists" (Luintel 2002, 47, citing Kantipur, September 11, 2001). Luintel (2002, 42) identifies the publication in Kantipur (April 8, 2002) of a photograph of a woman weeping over the dead body of her husband after the Maoist massacre of policemen at Naumule as the point at which the relationship between the Maoists and the Nepali media began to turn sour (see Figure 1). ${ }^{17}$

\section{The Royal Nepalese Army and the Press}

Even before the royal massacre, the mainstream Nepali newspapers took care to skirt issues that would bring the political role of the royal palace into dispute. The episode of the Maoists' armed assault on a police post at Dunai, the administrative headquarters of the district of Dolpo, on September 24, 2000, can serve as an example. This attack, in which fifteen police personnel were killed and eleven abducted, is generally regarded as a turning point in the People's War, after which the violence escalated rapidly. Every mainstream daily newspaper mentioned the nearby presence of a Royal Nepalese Army barracks in its report on this incident and recorded that the army did not come to the aid of the beleaguered police, but none asked why it was that the army did not engage the Maoists. To have done so would have been to raise sensitive questions about the political loyalties of the army, an issue that became increasingly important as events unfolded. ${ }^{18}$ The controversy became a matter for

${ }^{17}$ This photograph is reproduced from Thapa $(2003,1)$.

${ }^{18}$ Article 118 of the 1990 Constitution provides for the king to "operate and use" the Royal Nepalese Army “on the recommendation of the National Defense Council." This consists of the prime minister (as chairman), the defense minister, and the commander-in-chief. Ac- 


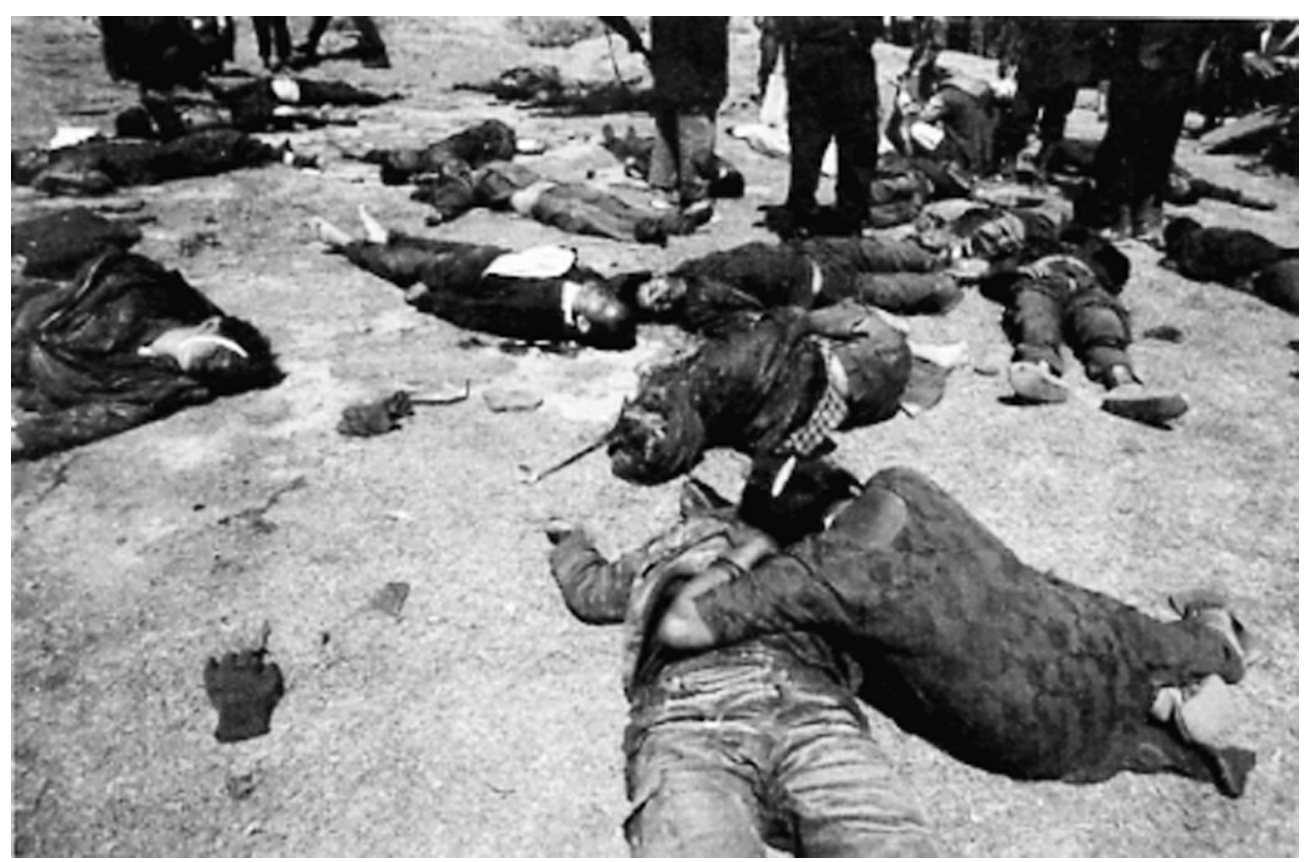

Figure 1. The widow of constable Lokendra Giri of Rolpa breaks down over his dead body. Giri was killed in the Maoist attack in the Naumule, Dallekh district, April 2001.

public debate only after the then home minister, Govindraj Joshi, announced that, although it had been agreed that the army would encircle the Maoists, the army had not done so. Having made this announcement, Joshi promptly resigned. The press reported Joshi's resignation and reproduced his statement but did not report the widely held view that he had resigned because his statement had created tension between the government and the palace. ${ }^{19}$

The issue of the control and political loyalties of the Royal Nepalese Army came to a head during July 2001, when the Maoists attacked six police posts and abducted seventy-one policemen from their headquarters at Holeri in the district of Rolpa. At this point, the prime minister, Girija Prasad Koirala, ordered that the army should be deployed to release them. Soldiers were flown into the area, and Nepali newspapers reported that they had surrounded the Maoists and were advancing in a vigorous but disciplined manner. The papers continued this kind of coverage, quoting defense and home ministry sources, for about one week. In reality, what had occurred was a kind of standoff, with neither of the two sides engaging the other in combat. Shortly afterward, the army was pulled out. The press did not report the army withdrawal, however, adopting a policy that Aryal $(2002,32)$ describes as "I'll stay quiet if you'll

cording to Article 119, the king is the supreme commander of the Royal Nepalese Army, and he appoints the commander-in-chief on the recommendation of the prime minister (Dhungel et al. 1998). In theory, therefore, the army's actions are directed by an elected politician. In practice, however, it is well known that the army, staffed at senior levels by a preponderance of Ranas, has its first loyalty to the palace.

19 "Even after the Dunai incident, the newspapers could not break the tradition according to which a subject does not become a matter of public discussion until the politicians have spoken out [on the issue]" (Aryal 2002, 24). 
stay quiet" (tain chup mai chup). Soon afterward, having failed to compel the army to follow his orders, Koirala tendered his resignation.

\section{The Arrival of Overt Censorship}

Barbi aeko belama tyasko agadi ubbiera chekne koshish garna hundaina

(When there is a flood coming, you shouldn't stand in front of it and try to block it) $)^{20}$

Three rounds of talks were conducted between five government negotiators and three midranking Maoist leaders between August and November 2001. The Maoists put on the table three core political demands: for an interim government, the election of a constituent assembly to draft a new constitution, and the redesignation of Nepal as a republican state. The government made concessions by scrapping the publicsecurity regulations it had introduced in June and releasing sixty-eight Maoist detainees, and the Maoist side responded by dropping its demand for a republican state. The talks ground to a halt, however, after the Maoists' demand for a constituent assembly was rejected, and, on November 21, the Communist Party of Nepal (Maoist) leader, Prachanda, declared that there was no longer any point in continuing. On November 23, attacks were launched against the security forces in various parts of the country, and, for the very first time, the Maoists attacked the Royal Nepalese Army, at its base in Ghorahi in Dang. The Nepali press reported that fourteen soldiers and twenty-three policemen were killed and that a total of Rs 225 million was looted from banks. The Maoists also captured a very large quantity of arms and ammunition. Two days later, on November 25, 2001, Maoists killed twenty-seven policemen, a chief district officer, and four soldiers at Salleri in the eastern district of Solu.

On November 26, 2001, King Gyanendra declared a national state of emergency (hereafter, the Emergency). Taking its cue from the U.S.-led war against terror launched in the wake of the September 11, 2001, attacks on New York City and Washington, D.C., the Nepali government declared the Maoists to be terrorists and deployed the Royal Nepalese Army to fight against them. ${ }^{21}$ The king invoked Clause 1 of Article 115 of the 1990 constitution $^{22}$ to suspend the provisions that guaranteed freedom of thought and expression, peaceful assembly, and movement; that outlawed censorship; and that provided rights against preventive detention, to information, to property, to privacy, and to constitutional remedy. On the same day, the Terrorism and Destructive Activities (Control and Punishment) Ordinance (TADO) was promulgated by the king. In a section that would soon impinge greatly on the lives of journalists, the TADO defined the following as "accomplices of terrorists" (atankkariko matiyar):

(1) Anyone in contact with or engaged with any person or group involved in terrorist and destructive acts;

(2) anyone who provides any person or group involved in terrorist and destructive acts with information, or who assists in the provision of information, or who facilitates the flow of, publishes, or distributes information of any person or group involved in terrorist and destructive acts;

${ }^{20}$ Advice given to a journalist by a member of Nepal's parliamentary opposition (Mohan Mainali, personal communication with the author, July 21, 2002).

${ }^{21}$ The Nepalese Maoists had already been designated as terrorists by the government of India several days earlier.

${ }^{22}$ The clause reads: "If a grave emergency arises in regard to the sovereignty or integrity of the Kingdom of Nepal or the security of any part thereof, whether by war, external aggression, armed rebellion or extreme economic disarray, His Majesty may by Proclamation, declare or order a State of Emergency in respect of the whole of the Kingdom of Nepal or of any specified part thereof." 
(3) anyone who assists any person or group involved in terrorist and destructive acts, whether openly or secretly (pratyaksha va apratyaksha prakarko sabyog). (Acharya 2002/ 2003, 3)

On November 27, the Royal Nepalese Army asked in a letter to editors and publishers that all reports on its activities be submitted to its news department for confirmation before they were published (http://www.nepalnews.com, November 27, 2001), and, on November 28, the Ministry of Information and Communication issued a press circular that listed matters that could and could not be published and broadcast, as follows:

Matters not to be published/broadcast:

a. Anything that aims to create hatred or disrespect or that arouses contempt or enmity against His Majesty the King or the Royal Family or that diminishes respect for (pratishthama anch aune) His Majesty.

b. Anything that is likely to harm the sovereignty and territorial integrity of the Kingdom of Nepal.

c. Anything that disturbs security, peace, and order in the Kingdom of Nepal.

d. Anything that is likely to create misunderstanding and communal hatred between the people of different castes, ethnic communities, religions, classes, regions, and communities (sampraday).

e. Anything that is likely to hurt the decent behavior, morality, and social dignity of the people.

f. Reports that are opposed to (pratikul) the Constitution of the Kingdom of Nepal, 1990.

g. Reports that damage the fundamental values of multiparty democracy.

h. Anything that is likely to harm the national identity, bring about social disruption, and spread terror.

i. Reports that are likely to spread bad feeling toward the Royal Nepalese Army, the Nepal police, and civil servants, lower their morale, and damage their reputation.

j. Reports of a type that offer support to Maoist terrorist individuals or groups or boost their morale.

k. Material that aims at overthrowing the elected government by the use of violent means.

1. Material of a sort that will create unnatural fear and terror in the public mind.

m. Material that demeans, disrespects, insults, and undervalues any caste, language, religion, or culture.

Matters to be published/broadcast:

a. Reports that expose the criminal activities of Maoist terrorists, but remaining alert not to raise the morale of the terrorists.

b. Reports on the bravery and achievements of the Royal Nepalese Army, the police, and national servants.

c. Official reports that come from His Majesty's Government and government media. (Nepal Samacharpatra, November 29, 2001)

All of the main political parties voiced their support for the three-month Emergency. ${ }^{23}$ The minister for communications said the government had no intention of gagging the press, and news media managers agreed that their journalists should wield their pens in support of parliamentary democracy and to oppose terrorist forces

${ }^{23}$ The Emergency was renewed on February 22, 2002, with majority support in parliament, and again, more controversially, on May 27, 2002. 
(see Bhattarai 2004, 14). The Federation of Nepalese Journalists (Nepal Patrakar Mahasangh) appealed to journalists to be alert (sajag) and disciplined and asked the government not to discourage journalists from conducting their responsible professional activities unhindered (Rajdhani, November 28, 2001).

Matthew Little suggests that "the potentially vulnerable position of editors in the hierarchy of news should not disguise the fact that they are more likely to be the perpetrators than the victims of censorship" (Little 2001, 717). In their editorials on the declaration of the Emergency, the national dailies each made a number of common points. The first was that there was a very clear difference between this emergency and the emergency of 1960, when King Mahendra dismissed the recently elected Congress government:

Because the country now has to face a state of emergency again after an interval of forty-one years, those belonging to the generation of up to about five decades in age lack any experience of emergency conditions. Also, most citizens are ignorant of the difference between the state of emergency of forty-one years ago and the condition that has now been imposed. Many mistakenly believe that the state of emergency of 1960 and the current one are of the same character and nature. ("Sarkar ra Presko Dayitva" [Government and the Responsibility of the Press], Rajdhani, November 29, 2001)

The temporary and limited nature of restrictions on civil liberties was stressed:

This hard (kathor) step, taken for the protection of the constitution, is a temporary one, and times come regularly in the history of a/the country when civil society has to voluntarily suspend its freedoms and basic rights for the long-term enjoyment (upabhog) of democracy. (Kantipur, November 27, 2001)

The second common argument endorsed antiterrorism as the new orthodoxy. The need to fight terrorism had become the overriding priority:

Terrorism, which is now represented by the Maoists, has become everyone's common enemy. There is one shared aim behind the declaration of the Emergency: the organization that has become a symbol of terrorism must be finished. (Kantipur, November 27, 2001)

Several editors assured the government that censorship would not be necessary because the press would not step out of line:

In this situation it would be wrong for the government to get excited and go down the path of controlling the press too much. Nor should there be any question of the press getting overexcited in view of the country, the time, and the circumstances. The main thing is for all to fulfill their responsibilities seriously. Rather than government censorship of the press, self-control, that is self-censorship, can be more effective, democratic, and responsible. In this matter, the Nepali press is far ahead of the government's thinking, viewpoint, and expectations. ("Sarkar ra presko sambandha" [The Relationship between Government and the Press], Nepal Samacharpatra, November 30, 2001; emphasis added)

One editor, however, issued a warning about the danger of the Emergency being hijacked by opportunists who wanted to turn the political clock back in Nepal:

In these circumstances, innocent weevils (ghunharu) can be ground in the process of grinding the corn. Hence, the press and the government should remain especially 
alert and vigilant with regard to this sensitive practical aspect. If they are slow in keeping people well informed, then the innocent civil society will have to undergo unexpected loss and suffering. The security machine should focus on fulfilling the responsibilities it has been given while inflicting the minimum damage or no damage at all. In particular, in this sensitive situation, it will be best if it maintains a distance from the hearing and access (sunuvai ra pabunch) of local opportunists and conservatives (purvagrabi). This is Nepal, where someone who has been authorized to grind the corn can also, for reasons of implicit self-interest, be forced and obliged to grind the weevils too. ("Sarkar ra Presko Dayitva" [Government and the Responsibility of the Press], Rajdhani, November 29, 2001)

"Prior restraint is the heart and soul of censorship," writes Soli Sorabjee (2001, 1956), "It is far more inhibiting than subsequent punishment. Expression is snuffed out before its birth." Faced with this enthusiastic editorial endorsement of the Emergency, some commentators felt that the press had conceded too much too soon. Writing in Kantipur on December 8, 2001, Mahendra Bista asked whether its acceptance of the new restrictions represented self-restraint (samyam) or surrender (samarpan), whereas Tikaram Bhattarai considered the Emergency a challenge to both newspapers and the legal system (Kantipur, December 6, 2001). By and large, however, the editors of the national dailies did nothing to try to block the flood.

\section{The Nepalese Emergency of 2001-02}

Even before the Emergency was declared, the relationship between the press media and the security forces had not been an easy one. ${ }^{24}$ None the less, the onslaught on the press that followed the imposition of the Emergency was alarming. In its review of press freedom in Nepal during 2002, the International Press Institute reported: "Three journalists were killed because of their profession in 2002, hundreds were detained, often without any charges filed against them; the whereabouts of several were unknown; and some were reportedly tortured during detention, both physically and psychologically" (World Press Freedom Review 2002). Reporters without Borders went farther, declaring in a report released on March 26, 2002, that "Nepal, with at least 30 media professionals locked behind bars, is, without a doubt, the largest journalist jail in the world." 25

According to the Federation of Nepalese Journalists (2003, 161-66), a total of 176 journalists were arrested or abducted during the nine months of the Emergency. The vast majority of actions against the press were taken by the government's security forces. Of the scores of journalists arrested, many were released after less than a week and most within three months. Very few were charged with any offence. ${ }^{26}$

${ }^{24}$ Two allegedly pro-Maoist journalists (Milan Nepali and Amar Budha) had already been either imprisoned or missing for two-and-a-half years. On June 27, 2001, police seized all copies of Dishabodh, which carried a feature article and interview with the Maoists' supreme leader, Prachanda. On July 15, 2001, twenty-four journalists who were trying to reach Rolpa to cover the Holeri confrontation were held overnight in Dang and then expelled from the area.

${ }_{25}$ “Torture, Arbitrary Detention and Self-Censorship: Four Months Later: Consequences of the State of Emergency and of the Fight Against 'Maoist Terrorism' Attacks on Freedom of the Press," Reporters without Borders, March 26, 2002, http://www.rsf.org/article.php3?id_article $=902$.

${ }^{26}$ On November 28, 2002, fourteen journalists filed lawsuits against the government, claiming compensation for their detention, which they claimed had been illegal. For listings 
On November 26, 2001 (11 Mangsir, 2058), approximately two hours before the government declared the Emergency and enacted the TADO, three pro-Maoist newspapers were shut down by the police, who resorted to the simple measure of storming their offices, arresting all of the nine people on the premises, and confiscating the office equipment. These were the Janadesh weekly (a paper founded ca. 1990); the Janadisha daily, edited by Krishna Sen, which had been established earlier that year, during the period of negotiations between the government and the Maoists; and Dishabodh, a monthly edited by Mumaram Khanal. ${ }^{27}$ Sen and Khanal, who were not at their offices when the raids took place, went into hiding. ${ }^{28}$ Thus, the Maoist press was banished from the scene, or at least to the underground and the Internet. The non-Maoist press had now to reach an accommodation with the Royal Nepalese Army in conditions that closely approached those of military rule.

Many non-Maoist journalists and editors were subjected to brief detentions that appeared to be intended to intimidate them into toeing the correct editorial line. For example, Gopal Budhathoki and Bandhu Thapa, the editor of Sangbu and publisher of Deshantar weeklies, respectively, were each taken in and held for a few days by the army within one month of the Emergency. During their detention, they were exposed to verbal abuse and threats and forced to wear sacks over their heads. A Spacetime Daily reporter, Anuradha Paudel, also published a full account of her own brief detention (Paudel 2002).

Gopal Budhathoki's second arrest probably came as a result of his publishing an article in Sanghu on February 23, 2002, that criticized the Chief of Army Staff. Entitled "Pradhansenapatijyu! Ansuko mulya pani nabujhne ki?" (Army Chief! Don't You Understand the Value of Tears?), the article argued that the army chief should have returned to Nepal from a visit to Europe immediately after the massacre by Maoist insurgents of fifty-five soldiers at their barracks in Achham on February 17, 2002, and should also have attended their funerals.

Budhathoki was intercepted and arrested by plainclothes army personnel while riding his motorcycle home from work on March 3, 2002, and was held blindfolded and incommunicado for twenty-three days. On March 6, after a series of demands were made by other journalists and politicians for his whereabouts to be disclosed, Prime Minister Sher Bahadur Deuba announced in parliament that the army had

and further details of arrests and detentions of journalists in Nepal under the Emergency and subsequently, see Informal Sector Service Centre (2002a, 2002b), Amnesty International (2002a, 2002b, 2003), Yogi (2002), the Committee to Protect Journalists' country-wise annual reports "Attacks on the Press" (http://www.cpj.org), the Reporters without Borders' annual reports on Nepal at http://www.rsf.org, and entries for Nepal in the International Press Institute's annual World Press Freedom Reviews at http://www.freemedia.at.

${ }^{27}$ See reports in Rajdhani, Himalaya Times, Samacharpatra, and at http://www. nepalnews.com, all on November 27, 2001. Similar measures were taken at the onset of the Indian Emergency in 1975. On June 26, 1975, the day the two-year Emergency was declared, the Indian government issued the Central Censorship Order (CCO) and "Guidelines for the Press in the Present Emergency." The next day, there were predawn arrests of 253 journalists, an emergency edition of the Hindustan Times was snatched from the streets, and the power was cut to the presses of the Statesman (Ramadorai and Bhattacharya 2001, 1173).

${ }^{28}$ Mumaram Khanal was arrested in early 2002 and released on July 29, 2003. Krishna Sen was finally arrested on May 20, 2002, and is widely believed to have died in custody. Sen's case is probably the most notorious to have emerged from the Emergency period. The report of the commission of inquiry into allegations of his death has been roundly dismissed as a whitewash. See "Nepal. The Death in Detention of Journalist Krishna Sen and a Regime's Lies," Reporters without Borders, October 15, 2002, http://www.rsf.org/article.php3?id_ article $=4047$. 
detained Budhathoki for publishing reports that "encouraged and raised the morale of the Maoists" and described him as atankkariko matiyar, "an accomplice of the terrorists." When he was released, he was warned not to write anything that would demoralize the army again. ${ }^{29}$

The extent to which journalists and editors were vulnerable to punitive action varied considerably, depending on whether they were located in Kathmandu or the provinces. Similarly, journalists' vulnerability also depended on whether they wrote in Nepali, English, or another language. The army's main concern seemed to be the impact their writings would have on public opinion in rural areas, and it was less concerned about the opinion of the educated elite and the foreign readership. Accordingly, local journalists in the outlying districts (mophasal) were very often treated much more roughly than those in the capital.

To avoid the unwelcome attentions of the army, editors fought shy of images that might be seen as provocative. Rajendra Dahal, editor of the fortnightly Himal Khabarpatrika, was faced with a dilemma over what image to select for the front cover of the issue of his magazine that followed the announcement of the Emergency (its editorial deadline was three days later) and opted for the face of the Royal Nepalese Army's chief of staff. On the morning the magazine appeared on the news stands, Dahal was summoned to the home of the army press officer to explain himself. Similarly, the cover of the issue printed immediately after the dissolution of parliament in May 2002 depicted the prime minister being moved about as a chess piece (see Figure 2). The prime ministerial chess piece was shown being moved towards another piece labeled "democracy" (prajatantra), and a voice bubble contained the word "check!" The Himal office received a phone call from the army asking them whose hand it was that was holding the chess piece. Dahal had rejected a photo of a soldier sitting on a ballot box for his front cover on the grounds that the army might think it suggested that it was opposed to democratic processes. Similarly, when the royal household's budget was increased by 233 percent in July 2002 despite the loss the previous year of ten of its members, comment in the press was initially muted (Rajendra Dahal, personal communication with the author, July 14, 2002), though it became much bolder after the king's dismissal of the prime minister in October 2002.

Investigative journalism, which did not have very deep roots in Nepal, virtually ceased under the Emergency. In his excellent month-by-month review of coverage in the Nepali dailies, Binod Bhattarai cites the case of an early government pronouncement that doctors and health workers should not provide treatment for Maoists injured in clashes with the security forces: "Not one newspaper bothered to investigate if hospitals and clinics had abided by the decision, or how such a directive would affect them" (Bhattarai 2004, 18).

After the 2001 Emergency was declared, the Maoist leadership went deep underground to avoid arrest and severed most of their links with the Nepali news media. They also became less friendly to their journalist friends, claiming responsibility for the murder of a newspaper editor in June 2002 and also abducting two Radio Nepal journalists. ${ }^{30}$ Bereft of their Maoist sources, constrained by the list of news items they

${ }^{29}$ Gopal Budhathoki, personal communication with the author, July 15, 2002.

${ }^{30}$ Nava Raj Sharma, editor of the Nepali-language weekly Kadam, was kidnapped from the Kalikot District village of Syuna by Maoist rebels and later killed. Previously, he had been held by the Maoists for three months (from February to May 2002) and then for three days by the security forces. Demling Lama, a correspondent in Sindhupalchok District for both Radio Nepal and the Nepali-language daily Himalaya Times, was kidnapped by Maoist rebels. He 


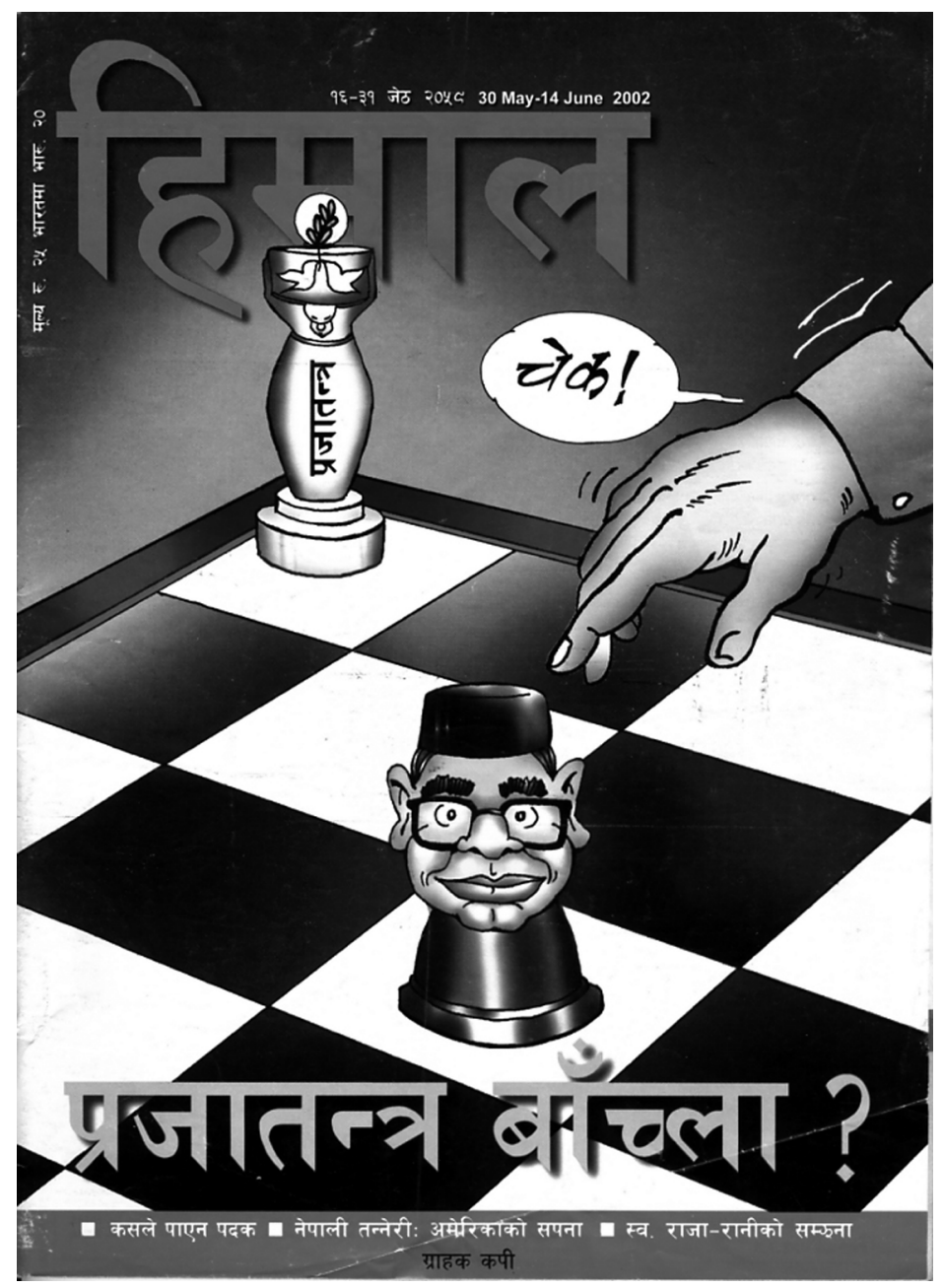

Figure 2. The cover of Himal Khabar Patrika (30 May-14 June 2002), showing the prime minister, Sher Bahadur Deuba, being used as a chess piece to defeat democracy. The headline translates as "Will Democracy Survive?"

were not permitted to cover, prevented from traveling to conflict areas without army permission (which was never granted), with their reports closely monitored, and with up to thirty colleagues in jail at any given time, Kathmandu-based Nepali journalists simply based their reporting of the People's War on bulletins issued by the army and the Defense Ministry. This was probably also partly a matter of cost: "Taking information from sources that may be presumed credible reduces investigative expense, whereas material from sources that are not prima facie credible, or that will elicit criticism and threats, requires careful checking and costly research" (Herman and

managed to escape after two days. His captors had accused him of being a government spy. Dhan Bahadur Rokka Magar, a newsreader for the Kham Magar-language service of Radio Nepal, was abducted by Maoist rebels while traveling by bus to the town of Surkhet. On March 21, 2005, it was reported on Radio Nepal that he had been murdered six months after his abduction. 
Chomsky 1994, 19). After the editor of Nepal Samacharpatra fell foul of the authorities for reporting a statement from the Maoist leader Prachanda on December 31, 2001, no national daily reproduced any of the Maoist statements that continued to reach them via fax and e-mail until April 2002 (Bhattarai 2004, 24, 36). Even then, they were heavily edited to remove pejorative references to the royal family.

As a consequence of this reliance on the army and the Defense Ministry, a particular kind of report now began to appear monotonously in the national dailies. A typical example would begin with the phrase "In security operations across the country today [x number of] terrorists have been killed." Often, the terrorists were reported to have died in encounters (bhidanta). In the early weeks of the Emergency, such reports were front-page news, but gradually they became briefer and were increasingly relegated to inner pages, unless the number of casualties was especially large. The number of casualties on the Maoist side appears often to have been considerably inflated by the Defense Ministry (see Dixit 2002a; Mehta 2002). Very little further information was offered on the identity of those who had died or the manner of their deaths. It was only rarely admitted that innocents had died in crossfire and very rarely reported that any prisoners had been taken. Local reporters simply laid down their pens, unable to report on what they knew was happening in their districts for fear of the security forces on the one hand and the Maoists on the other. ${ }^{31}$

\section{Worthy and Unworthy Victims}

\section{The Relatives' Laments}

The armed conflict between the Communist Party of Nepal (Maoist) and the Royal Nepalese Army was brutal in the extreme during the early months of the Emergency. The army took no prisoners, often shooting Maoists and suspected Maoists on sight. The Maoists also considered police and army personnel to be valid targets in all circumstances and were accused several times of simply executing those captured in assaults on police and army posts. Thus, the Nepali countryside rapidly filled with victims: widowed women, orphaned children, extended families bereft of the young men who had been their mainstay. Although journalists were not granted access to areas where the conflict was in full swing, those who were losing their lives hailed from all over Nepal, and their bodies were being returned to villages in every district. As a consequence, a new marked category of news report began to appear in the national dailies, which told the story of a particular soldier or policeman who had been killed in action and the consequent plight of his family. ${ }^{32}$ Each story contains many common elements: There are frequent mentions of messages received from the policeman or soldier shortly before his death, and his family often state with sorrow that he was not able to return home during the last Dasain festival:

Having watched the neighbors' children walking about, each with their own father, and seeing their fathers bringing them toys and things to eat, Ram's children had

${ }^{31}$ Kashi Ram Dangi (Kantipur reporter, Rolpa district), personal communication with the author, July 10, 2002.

${ }^{32}$ The titles of these articles all translate loosely as "Relatives' Lament" or "Relatives' Sadness"; the Spacetime variant has "the Suffering of the Maoist-Afflicted." These reports were photocopied from the archive of Emergency-period reporting at the Social Science Baha in Kathmandu in July 2002. My thanks to Sangeeta Lama and Deepak Thapa. 
begun to look for their father too. After they began to ask her where their father was, where he had gone, and when he would come home, Police Officer Ram's wife had written to him, telling him to come home for Dasain no matter what, but he did not get the chance to do so. . . . Now the children's wish to have their father buy them toys and lovely things will never be fulfilled, Ram's wife's niece told Nepal Samacharpatra tearfully. ${ }^{33}$

Stress is laid upon the bleak future now faced by the dead man's wife, elderly parents, and young children (in several cases, these are babies born since his departure from his home):

My suckling baby is in my lap, my sindur has been wiped away, how can I survive now? How can I make this child's future? ${ }^{34}$

Each family utters defiant messages to the Maoists. Some even express patriotic pride that their son or husband has achieved martyrdom (shahadat or virgati):

26-year old Goma, who has become a widow because of the Maoists, says that the road taken by the Maoists is wrong for the country and the people: "Although the parting of my hair is empty (ujar) and I am alone, I do not feel alone. I want to encourage the wives of all of the men working in the police force to send them out onto the battlefield for the sake of the nation and nationhood." 35

Thus far, these reports do not contravene the Emergency guidelines. A dissenting note does appear in several, however, which suggests that those who have lost family members are not being cared for properly by the state. The brother of a soldier killed in the second Maoist attack on Salleri complains that those with source (sors bunebaru), that is, those related to senior figures in the army establishment, were seldom posted to Maoist-affected areas, but his brother had already served in the Maoists' base area districts of Rolpa and Rukum. ${ }^{36}$

\section{The Girl in the Burning Bus}

One of the most potent images of Maoist evil was that of the death of an eightyear-old girl named Kajol Khatoon. According to a report published in Nepal Samacharpatra on February 23, 2002, this occurred in the following manner (see Figure 3). The Maoists had called a Nepal band, a complete nationwide shutdown of all vehicular traffic and commercial activity, enforced with threats of violence. A privately owned passenger coach plying between Kathmandu and the southern border town of Birganj was stopped on the road at about 4:00 a.m. by some young women posing as travelers.

${ }^{33}$ Krishna Bhattarai, "Buwalai bhetne tin varshadekhiko uniharuko chahana adhurai rahyo" (Their Wish since Three Years to Meet their Father Remained Unfulfilled), Nepal Samacharpatra, November 29, 2001. About policeman Havildar Ram Rajbhandari, killed at Salleri.

34"Amako upachar garne ra chorako anuhar herne chahana adhuro" (Wish to Treat His Mother and Look at His Son's Face Unfulfilled), Nepal Samacharpatra, February 23, 2002. About a soldier named Bhuvandorje Tamang, killed at Mangalsen one week earlier.

${ }^{35}$ Tikaram "Neti," "Tuhura chorachorilai sanrakshan dina amako agraha" (Mother's Request for Maintenance of Her Orphaned Children), Nepal Samacharpatra, February 6, 2002. About Govinda Thapaliya, killed at Gopetar.

36"Bhanekai samayma ayo tara mutu tukratukra parne gari ayo" (He Came Home When He Said He Would, But He Broke Their Hearts When He Came), Nepal Samacharpatra, November 30, 2001. 


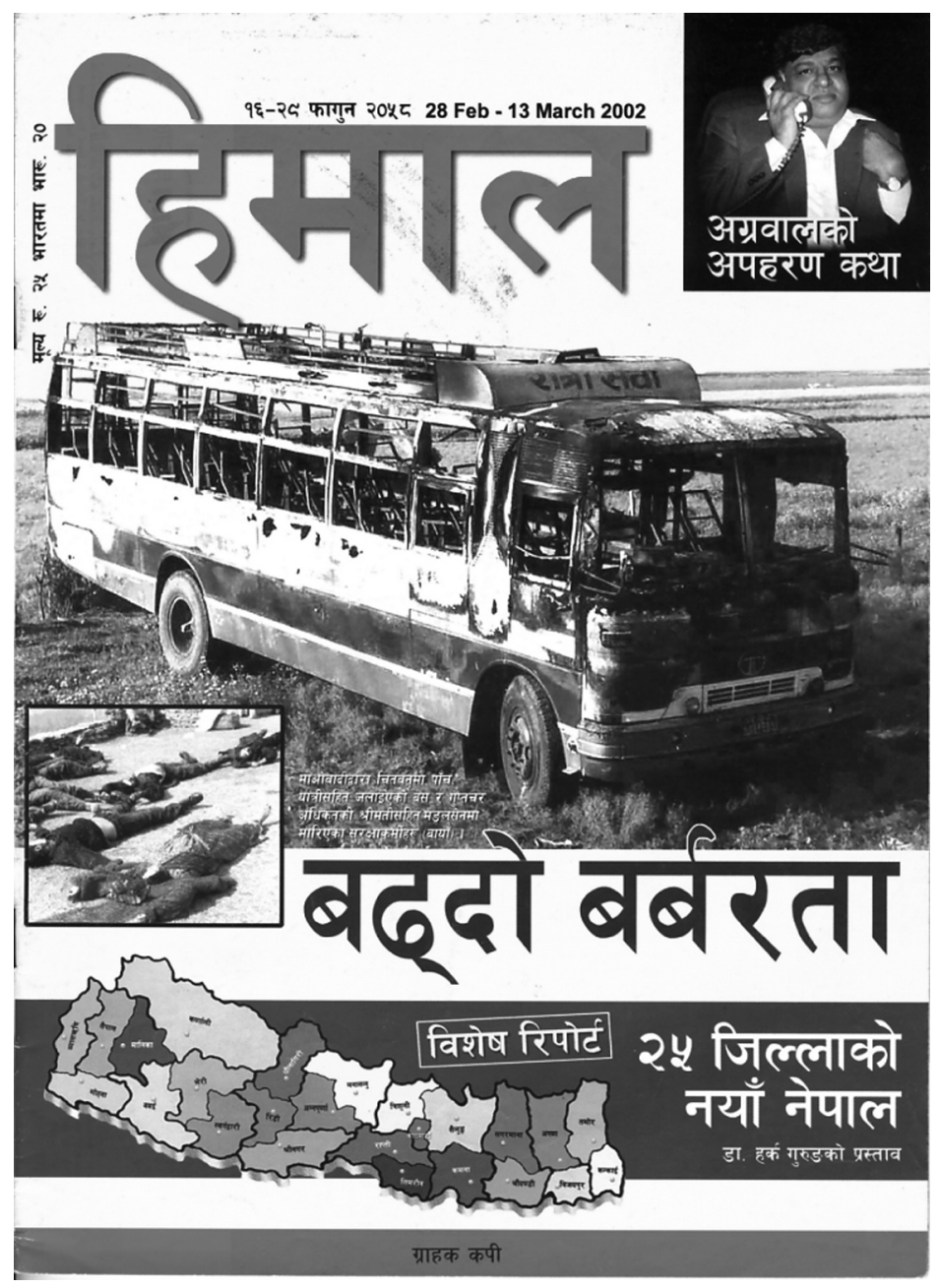

Figure 3. The cover of Himal Khabar Patrika (28 February-13 March 2002), showing the bus in which Kajol Khatoon and five others died. The headline translates as "Increasing Barbarism".

After the bus had stopped, about fifteen armed people, mostly women, emerged from the undergrowth, poured liquid fuel all over the bus, and set it on fire. One witness said that they entered the bus and shut the windows before setting it on fire, ignoring demands that they let the passengers out first. Those passengers who were awake smashed windows and escaped, but those who were asleep did not. Five Birganj residents died: Kajol Khatoon (age eight), Jahir Husen Ansari (age thirty-five), Sabir Miya Ansari (age twenty-eight), Jakir Ansari (age thirty), and Sulman Ansari (age twenty). They were all Muslims returning home for the last day of Id. The Nepal Samacharpatra report began, "On Friday morning, even before Swayambhu had opened its eyes of peace, the Maoists created a scene in reality that was even more terrifying than the cruelest cinema scene and were determined to show themselves fully in the 
category of terrorists." ${ }^{37}$ Kajol Khatoon has since appeared in poems such as "Kajol, the Earth Is Still Dark" by Chandra Kishor:

Yes Kajol,

No light has appeared here yet,

The earth is still dark.

Bombs are growing up from the green ground instead of grain,

The environment is suffocating in the acrid smoke of gunpowder,

A contemptible hunt is going on.

But no one is innocent,

Whoever you blame, only you are innocent, Kajol!

Although you fell prey to pitilessness,

No one is burning in the fires of remorse. ${ }^{38}$

\section{The Murdered Headmaster}

A second image of the Maoists' viciousness that circulated widely is a photograph of a schoolteacher named Muktinath Adhikari (see Figure 4). Adhikari's body is kneeling in front of a tree. His arms are behind him, around the trunk of the tree, to which they are tied. His eyes are closed, and his mouth hangs slightly open. Forty-five-yearold Muktinath Adhikari was taking a mathematics class in the Panini Sanskrit Higher Secondary School in the small hill town of Duradanda on January 16, 2002, when a group of armed Maoists arrived and took him away. On a hillside overlooking Duradanda, they tied him to a tree by his scarf, stabbed him in the shoulder and chest, and shot him in the right temple. The villagers had been warned not to remove the body, and it remained there for more than twenty-four hours until a group of officials arrived by police helicopter. The explanation given for his execution was that he had been informing on local Maoist activists, had refused to hand over 25 percent of his annual Dasain bonus, and had persisted in teaching Sanskrit despite warnings that he should no longer do so. He was also a member of a teachers' union and the local convener of Amnesty International. The image of a schoolteacher being dragged to his death from a classroom was an unusually disturbing one, and the case caused an international wave of revulsion. A report in Himal Khabarpatrika took the atrocity as an opportunity to castigate the mainstream political parties for their silence:

This time it is a village in Lamjung that has had the misfortune to suffer an event that eclipses even the cruelty of infamous dictators. A defenseless teacher has become the victim of Maoist terrorism. But however contemptible the Maoists' cruel violence may be, the lack of concern shown by the political parties about this incident is equally surprising and irresponsible. ${ }^{39}$

\section{The Laborers from Jogimara}

Herman and Chomsky (1994) would probably recognize all of the previous as examples of a propaganda system's portrayal of so-called worthy victims. In most of

37 "Baliraheko basbhitra jaliraheka thie idka khushiharu" (The Joys of Id Were Burning inside a Blazing Bus), Nepal Samacharpatra, February 23, 2002; "Mama . . mama bhandabhandai jalisakeki thiin uni" (Crying "Uncle, uncle," She Burned to Death, Kantipur, March 6, 2002.

${ }^{38}$ Himal Khabarpatrika, October 2-November 1, 2002: 70.

39"Ek shikshakmathi maovadiko krurata, rajnaitik dalharuko durbhagyapurna maunta" (The Maoists' Cruelty to a Teacher, the Unfortunate Silence of the Political Parties), Himal Khabarpatrika, January 29-February 12, 2002. 


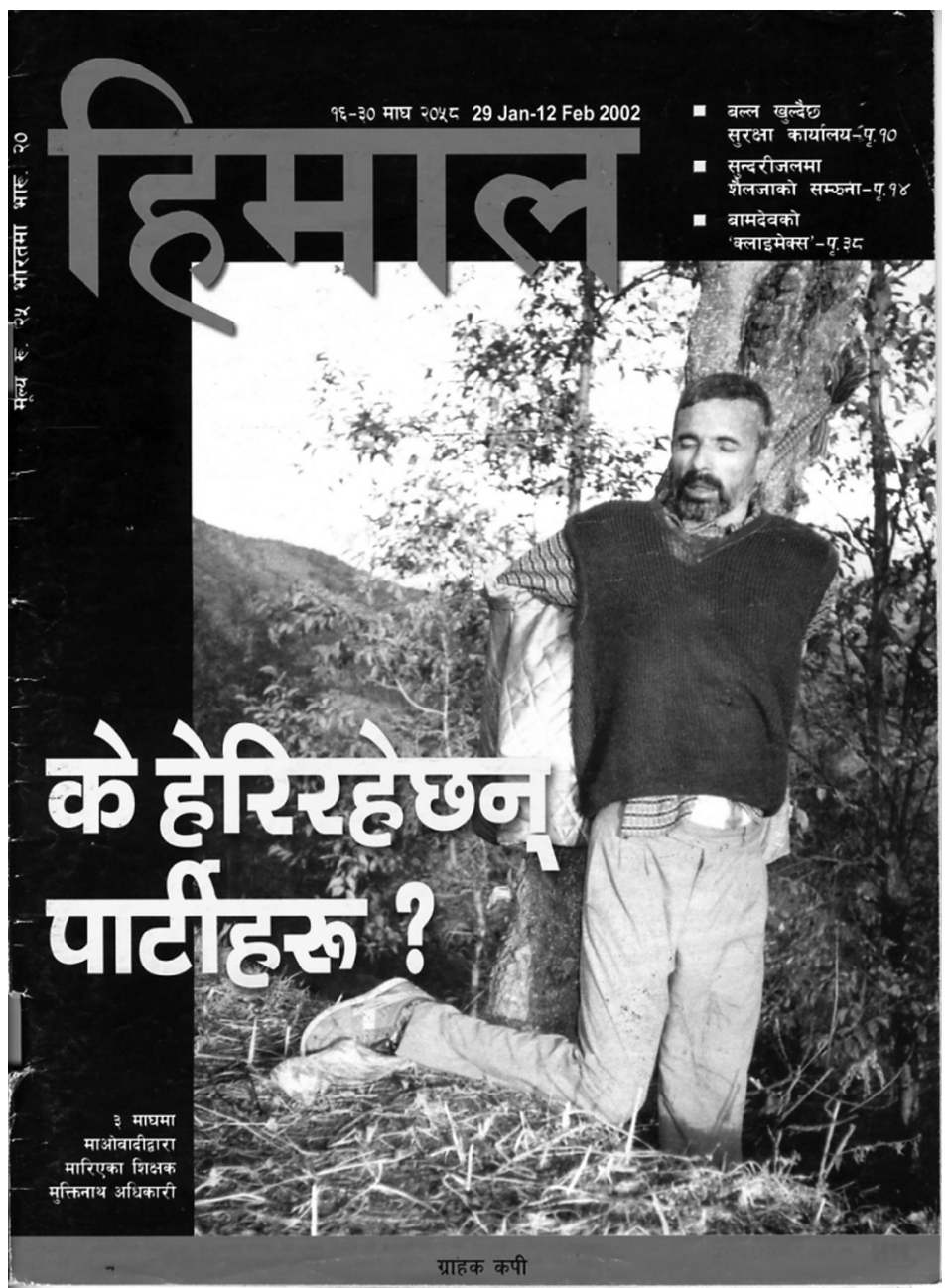

Figure 4. The cover of Himal Khabar Patrika (29 January-12 February 2002), showing the dead body of Muktinath Adhikari. The headline translates as "Are the Parties Watching?"

the press coverage of the conflict, military actions by the army brought about the deaths (mrityu) of Maoists, whereas Maoist killings of security officials were nearly always murders (hatya). Moreover, there was virtually no coverage in the national Nepali press of the human rights abuses that were widely known to be occurring at the hands of the security forces (a story in Kantipur of May 6, 2002, that reported the killing by security forces of six villagers in Thulo Sirubari was an isolated exception; Bhattarai 2004, 47).

As the Emergency entered what were to be its final weeks in summer 2002, journalists began to publicize the cases of a number of unworthy victims, alleging that the Royal Nepalese Army was guilty of atrocities comparable to those committed by the Maoists. The first such article of any substance was written by Mohan Mainali and appeared in the Nepali-language magazine Himal Khabarpatrika in mid-July 2002. A shorter article on the same subject appeared in the English Nepali Times two weeks later. The first page of the ten-page article in Himal consisted of the title 
"Mrtyubhanda kathor sajay" (A Punishment Worse than Death) and the following declaration, printed in large bold text:

Many feared that the Emergency could create a situation like this. Therefore, they had hoped that it would not. However, the thing they feared has happened: Not only have a dozen poverty-stricken families of Dhading Jogimara, which is backward in every way-economic, educational, social-had to lose one-and-a-half dozen of their promising young (honahar) relatives, they have also had to be slurred as "relatives or allies of terrorists." The cause of their misfortune is none other than that same kingdom that forced them to risk hot bullets in order to feed themselves. If the government is not going to take responsibility for the injustice and atrocity (atyachar) that has befallen these helpless people of Jogimara, and if no one is going to raise a voice against the injustice done to them, then Nepal and all Nepalis are going to have suffer the tragic consequences. (Mainali 2002, 27)

Mainali's report begins: "Gairigaun, 21 Asar [July 6, 2002]. After Pandit Navaraj Sharma Adhikari arrived at about 10:00 a.m., the weeping began in Belbahadur Shrestha's thatched two-story house. It began inside the house with the sobbing of Belbahadur Shrestha's wife and gradually increased." The scene described is one in which Belbahadur Shrestha is preparing to perform the funeral rites for his twentyeight-year-old son, Rajkumar. Belbahadur has not received his son's body, however. Therefore, the family is following an age-old custom according to which, when a person is known to have died but their body cannot be recovered, an effigy (putla) made of kush grass is cremated in its stead. It is explained that Rajkumar Shrestha was one of twenty young men from the village of Jogimara in Dhading, most of them low-caste and exceptionally poor, even by Nepali standards, who had traveled to Kalikot at the end of 2001 in order to work as contracted laborers on the construction of an airstrip. Some weeks after their arrival there, the Maoists attacked the security forces at Mangalsen and Sanfebagar, killing more than 125 policemen and soldiers. Ever since this catastrophe, the army had been in pursuit of the insurgents across the hills to the north. On February 24, 2002, thirty-five people were shot dead by the Royal Nepalese Army at the construction site. Of these thirty-five, seventeen were young men from Jogimara, nine of them less than twenty-one years of age. Their deaths had widowed ten women and orphaned eighteen children. At the end of the week in which the thirty-five construction workers died, the Ministry of Defense announced that sixty-seven Maoists had been killed during encounters in Kalikot.

Mohan Mainali's report struggles to paint a picture of almost indescribable mis$e^{2 y}{ }^{40}$ and places the blame squarely on the Royal Nepalese Army. At last, Nepal's embattled journalists had begun to reassert themselves.

\section{Conclusion}

Since 1990, the main restrictions on freedom of investigation, speech, and publication in Nepal have reflected a felt need to protect the interests of the palace. Indeed, these restrictions are enshrined in two articles of the 1990 constitution:

Article 31: Question not to be Raised in Courts. No question shall be raised in any court about any act performed by His Majesty. Provided that nothing in this Article shall

${ }^{40}$ The same story is the subject of a thirty-eight-minute film entitled The Living of Jogimara, produced by the Himal Association. 
be deemed to restrict any right under law to initiate proceedings against His Majesty's Government or any employee of His Majesty. (Dhungel et al. 1998, 240)

Article 56 (1): No discussion shall be held in either House of Parliament on the conduct of His Majesty, Her Majesty the Queen and the heir apparent to His Majesty. Provided that nothing in this Article shall be deemed to bar criticism of His Majesty's government. (Dhungel et al. 1998, 344)

Dhungel et al. (1998) observe that restrictions like these are "common to most constitutional monarchies" and they argue that:

In view of the King's status as the constitutional monarch (bound by Article 35(2) and other provisions of the Constitution, and with a dignified role in symbolising the country and its people) there could be no conduct on his part, which could legitimately be subjected to criticism. Offensive expressions against the character and conduct of such a national luminary would not only be contempt of his supreme status, but also a calculated attempt to degrade the nation in the public estimation. (Dhungel et al. 1998, 345)

Such restrictions may be said to be enforced, to borrow Mill's expressions, by the "likings and dislikings" of a "powerful portion" of society, but in Nepal, they were enforced for perhaps ten generations and came to resemble a societal consensus. Moreover, in practice, the restrictions did not apply merely to comments on the acts or conduct of the monarch; they extended to any discussion of any issue if it ran the risk of turning into a consideration of the political role of the palace.

The question that arose in Nepal during the period under consideration here is one about whether it was still possible to maintain and operate democratic processes and institutions even as a powerful, politically active (and latterly extraconstitutional) palace and its army remained at the core and center of an expanding sphere of bhanna nabune kura. The period between the end of the 2001-02 Emergency and the beginning of the Emergency of 2005 saw a strange mixture of both greater autocracy and greater press freedom. On the one hand, the royal-military nexus marginalized the parliamentary parties and arrogated executive power to itself. On the other hand, however, the possible advantages of a republican state were very openly debated, and Maoist leaders published opinion pieces in newspapers such as Kantipur on a regular basis, with no action being taken against the newspapers' editors or proprietors. In February 2005, of course, this public discourse ceased abruptly and was relegated to the Internet (see, e.g., International Nepal Solidarity Network for Democratic Peace at http://www.insn.org). 41

Although the reluctance of Nepal's media to dig too deep in the matter of the royal massacre reflected older codes of deference and secrecy, the Maoist insurgency, the 2001 Emergency, and the deployment of the Royal Nepalese Army saw this old societal restriction on free public discussion reinforced and extended to include discussion of the conduct of the army, too. The operation of overt censorship became very readily discernible during the Emergency, in the shape of detained journalists and editors, whereas the practice of self-censorship produced only a muted discussion of the royal massacre and resulted in the total absence for a period of nearly eight months of any coverage of security-force atrocities.

${ }^{41}$ This and several other Web sites were blocked by the Nepal government from mid2005 onwards. 
Censorship actions are often motivated by the likely audience that written material might reach, revealing "a fear of the lower orders and especially of their growing politicization" (White 2001, 310). Although elites may discuss certain issues among themselves, ideally in an elite language, they should not transmit them to the vernacular masses (see Harrison 2001, 564). Thus, the Royal Nepalese Army tended to respond with greater alacrity to negative coverage in Nepali than to critical coverage in English and with greater force to reports published in the districts than to those printed and circulated in Kathmandu. If members of the English-speaking elite based in the capital were critical, this could be suffered, but the rural masses had to remain submissive and quiescent, and attempts to encourage them to question the actions of the Royal Nepalese Army were not to be tolerated.

Mill acknowledges a need for certain rules of conduct in society and certain restraints upon people's actions and accepts that these may be imposed by law in some cases and by opinion in many others:

What these rules should be, is the principal question in human affairs; but if we except a few of the most obvious cases, it is one of those which least progress has been made in resolving. No two ages, and scarcely any two countries, have decided it alike; and the decision of one age or country is a wonder to another. (emphasis added) (On Liberty, 1869)

The argument that societal discourse is conducted within parameters that are fixed by an ascendant, powerful class holds true in relation to news media in all languages and societies. The nature and extent of its validity, however, is subject to variation because the ascendant class in each society has its own historical trajectory and functions in its own medium and against its own specific sociocultural backdrop. Sweeping assumptions about media globalization tend not to take such local vernacular factors into account.

Harrison describes a medium of shared assumptions as a "defining characteristic of a society":

There is no guaranteed route to an outside, transcendent perspective on such censorship ... or on the "limits" it enforces, though both the censor and the counter-censor are obliged to pretend that they can speak from such a perspective, to speak as if they know the true reasons for censorship that lie behind the tautological (but mobile) category of that-which-should-be-censored. (Harrison 2001, 565)

Ultimately, news content is always the end product of a process of continual, almost daily, negotiation between the commercial interests of proprietors, the tolerance or intolerance of the state authorities and the sanctions they are prepared to apply, the readership's demands and expectations, and journalistic integrity and competence. The ease with which the dissenting voice of Nepal's vibrant and newly free media was silenced during this period, and the way in which it was raised again until a new Emergency silenced it once more, illustrates the profundity of the sociopolitical change that Nepal is undergoing. The profundity of such a change in such a country cannot be fully apprehended without recourse to this kind of crucial internal debate, conducted in a nonglobal language. It reduces the extent to which this one country's decisions are "a wonder to another," by shedding light, in a way no other discourse can, on the impact zone in which opposing views of rights, freedoms, and a nation's destiny collide. 


\section{List of References}

Acharya, Dilliraj. 2002/2003 (2059 V.S.). Sankatkal ra sankatkalin abbivyaktiharu [The Emergency and Emergency Period Statements]. Kathmandu: Nirantar Prakashan.

AdHIKARI, Prakash. 2002. "Darbar hatyakandako ainama nepali patrakarita" [Nepali Journalism in the Mirror of the Palace Massacre]. In Midiyako antarvastu: vividha vishleshan [Media Content: Various Analyses], ed. Pratyoush Onta, Ramesh Parajuli, and Rama Parajuli. Kathmandu: Martin Chautari/Samajik Vikas tatha Anusandhan Kendra.

Amnesty International. 2002a. Nepal: A Spiralling Human Rights Crisis. ASA 31/016/2002.

- 2002b. Nepal: A Deepening Human Rights Crisis. ASA 31/072/2002.

. 2003. Nepal: Widespread "Disappearances" in the Context of Armed Conflict. ASA $31 / 045 / 2003$.

Aryal, Prashanta. 2002. "Nepali chapama dunai kandapachiko maovadi vidroha" [The Maoist Rebellion in Nepali Newspapers after the Dunai Episode]. In Midiyako antarvastu: vividha vishleshan, ed. Pratyoush Onta, Ramesh Parajuli, and Rama Parajuli. Kathmandu: Martin Chautari/Samajik Vikas tatha Anusandhan Kendra.

Basnet, Purna. 2002. "Asurakshako gherabandima patrakar" [Journalists Surrounded by Insecurity]. Mulyankan 99 (Saun 2059).

Bhattarai, Baburam. 2001. "Naya kotparva lai manyata dinu hundaina" [We Should Not Recognize the New Kot Massacre]. Kantipur, 6 June 2001.

Bhattarai, Binod. 2004. Nepali Press under Emergency: A Survey of the First Six Months. Kathmandu: Himal Books.

Curran, James. 1992. “Mass Media and Democracy: A Reappraisal." In Mass Media and Society, ed. James Curran and Michael Gurewitch. London: Edward Arnold.

DAhal, RAJENDRA. 2002. "Maovadi andolan, sarkar ra nepali pres" [The Maoist Movement, the Government and the Nepali Press]. In Midiyako antarvastu: vividha vishleshan, ed. Pratyoush Onta, Ramesh Parajuli, and Rama Parajuli. Kathmandu: Martin Chautari/Samajik Vikas tatha Anusandhan Kendra.

Dhungel, Surya P. S., Bipin Adhikari, B. P. Bhandari, and Chris MurGATROYD. 1998. Commentary on the Nepalese Constitution. Kathmandu: DeLF Lawyers.

Dixit, Kanak Mani. 2001. "The Valley of Halla." Nepali Times 47 (15-21 June 2001).

—. 2002a. "Innocents and Insurgents." Himal South Asia 15(6):28-38.

- 2002b. "A New King and the Challenge of Democracy." In State of Nepal, ed. Kanak Mani Dixit and Shastri Ramachandaran. Kathmandu: Himal Books.

Federation of Nepalese Journalists. 2003. Nepali Press During State of Emergency. Kathmandu: Federation of Nepalese Journalists.

Gellner, David N., ed. 2003. Resistance and the State: Nepalese Experiences. Delhi: Social Science Press.

HACHHETHU, KRISHNA. 2001. "Rajparampara ra vidhima vyapak parivartan” [Extensive Changes in Royal Tradition and Practice]. Himal Khabarpatrika 11(6).

Harrison, Nicholas. 2001. "Complicity.” In Censorship: A World Encyclopedia, ed. Derek Jones. Chicago: Fitzroy Dearborn.

Herman, Edward S., and Noam Chomsky. 1994. Manufacturing Consent: The Political Economy of the Mass Media. London: Vintage Books. 
Humagai, Devraj. 2002. "Makwanpurko patrikarita ek adhyayan" [Journalism in Makwanpur: A Study]. In Kshetriya Midiya, ed. Pratyoush Onta. Kathmandu: Martin Chautari, Samajik Vikas tatha Anusandhan Kendra.

Hutt, Michael, ed. 2004. Himalayan People's War: Nepal's Maoist Rebellion. London: Hurst.

- 2005. "King Gyanendra's coup and its implications for Nepal's future." Brown Journal of World Affairs 12(1):111-23.

Informal Sector Service Centre (INSEC). 2002a. Human Rights Yearbook 2002. Kathmandu: INSEC.

. 2002b. Manavadhikar Varsha Pustak 2002. Kathmandu: INSEC.

Jeffrey, Robin. 2000. India's Newspaper Revolution. Capitalism, Politics and the Indian-language Press, 1977-1999. London: Hurst.

Karki, Arjun, and David Seddon, eds. 2003. The People's War in Nepal: Left Perspectives. Delhi: Adroit.

Kumar, Dhruba, ed. 2000. Domestic Conflict and Crisis of Governability in Nepal. Kirtipur: Centre of Nepal and Asian Studies.

Lecomte-Tilouine, Marie. 2004. "Regicide and Maoist Revolutionary Warfare in Nepal: Modern Incarnations of a Warrior Kingdom. Anthropology Today 20(1):13-19.

Little, Matthew. 2001. "Editors." In Censorship: A World Encyclopedia, ed. Derek Jones. Chicago: Fitzroy Dearborn.

Luintel, Gunaraj. 2002. "Maovadi ra pres: utsukta ra bhayko sambandha" [The Maoists and the Press: A Relationship of Excitement and Fear]. In Midiyako antarvastu: vividha vishleshan, ed. Pratyoush Onta, Ramesh Parajuli, and Rama Parajuli. Kathmandu: Martin Chautari/Samajik Vikas tatha Anusandhan Kendra.

Mainali, Mohan. 2002. "Mrtyubhanda kathor sajay" [A Punishment Worse than Death]. Himal Khabar Patrika 12(7):26-35.

Menta, Ashok K. 2002. "Shooting to Kill in Nepal." Himal South Asia 15(7):45.

Onta, Pratyoush. 2001. "Right to Information." The Kathmandu Post, 15 June 2001.

- 2002. "Critiquing the Media Boom." In State of Nepal, ed. Kanak Mani Dixit and Shastri Ramachandaran. Kathmandu: Himal Books.

- 2004. "Democracy and Duplicity: The Maoists and Their Interlocutors in Nepal." In Himalayan People's War: Nepal's Maoist Rebellion, ed. Michael Hutt. London: Hurst.

Parajuli, Rama. 2002. "Narayanhiti hatyakanda: 'brodshit'ko kabharej" [The Narayanhiti Massacre: "Broadsheet" Coverage]. In Midiyako antarvastu: vividha vishleshan, ed. Pratyoush Onta, Ramesh Parajuli, and Rama Parajuli. Kathmandu: Martin Chautari/Samajik Vikas tatha Anusandhan Kendra.

Paudel, Anuradha. 2002. "Patrakarle bhogeko hirasat" [The Detention Suffered by a Journalist] Spacetime, 23 January.

Press Council Nepal. 2001 (2058 V.S., Asoj). Chabbisau varshik prativedan [26th Annual Report]. Kathmandu: Press Council Nepal.

Ramadorai, Tarun, and Sanjoy Bhattacharya. 2001. "India: State Censorship and the Indian 'Emergency' of 1975-77." In Censorship: A World Encyclopedia, ed. Derek Jones. Chicago: Fitzroy Dearborn.

Salwen, Michael B. 2001. "Press: Authoritarian Control." In Censorship: A World Encyclopedia, ed. Derek Jones. Chicago: Fitzroy Dearborn. 
SANGRAula, Khagendra. 2001a. "Arko kotparva: sarkar rahasyavadi, janta kuhiroko kag" [Another Kot Massacre: Government Secretive, People are Crows in the Mist]. Kantipur 6 (June).

_ 2001b. "Bhatij Dipendra! Malai maph gara" [Nephew Dipendra! Forgive Me!]. Kantipur Koseli, 7 July.

- 2001c (2058 V.S., Saun). Itihasma Kalo Potieko Anubar [A Face Blackened in History]. Kathmandu: Antarkriya Prakashan.

Sorabjee, Soli J. 2001. "Prior Restraint." In Censorship: A World Encyclopedia, ed. Derek Jones. Chicago: Fitzroy Dearborn.

Thapa, Deepak. 2002. “The Maobadi of Nepal.” In State of Nepal, ed. Kanak Dixit and Shastri Ramachandaran. Kathmandu: Himal Books.

—, ed. 2003. Understanding the Maoist Movement of Nepal. Kathmandu: Martin Chautari.

Thapa, Manjushree. 2001. "Bhupi Sherchan on Rumor and Hearsay." Nepali Times 48 (22-28 June).

White, Barbara. 2001. "Britain 1688-1880." In Censorship: A World Encyclopedia, ed. Derek Jones. Chicago: Fitzroy Dearborn.

World Press Freedom RevieW. 2002. International Press Institute Web site, http://www.freemedia.at/wpfr/Asia/nepal.htm.

Yogi, Bhagirath, ed. 2002. Status of Press Freedom and Freedom of Expression: Nepal Report 2002. Kathmandu: Center for Human Rights and Democratic Studies (CEHURDES). 